\title{
Predictive models of efficacy and public health impact of vaccination with rotavirus vaccine in Ukraine
}

\author{
S. A. Solovyov ${ }^{1, \mathrm{a}}$, J. Rose $^{2}$, I. V. Dzyublyk ${ }^{1}$, E. P. Trokhimenko ${ }^{1}$ \\ ${ }^{1}$ The National Medical Academy of Postgraduate Education named after P. L. Shupyk, \\ Dept. of virology, \\ Dorogozhytska st., 9, Kyiv, 04112, Ukraine \\ ${ }^{2}$ Case Western Reserve University, \\ Dept. of Family Medicine, Div. of Research, \\ Cleveland, Ohio 44106, USA \\ E-mail: asolovyov@i.ua
}

Получено 21 декабря 2011 г., после доработки 2 апреля 2012 г.

\begin{abstract}
There were presented the results of the computational and theoretical studies related to assessing of an efficacy and public health impact of a vaccination with a rotavirus vaccine in Ukraine. The required indicators are: the genotype-specific vaccine efficacy, number of the severe illness preventions, hospitalizations, outpatient visits and deaths. The results were obtained in a form of tree of decisions based on Makrov model by using mathematical model with computer simulation. The results showed the significant positive effect of the vaccination compared to no vaccination, in case of high level of vaccine coverage in Ukraine.
\end{abstract}

Keywords: rotavirus, rotavirus vaccine, vaccination, decision tree, Markov model

\section{Прогностические модели эффективности и медицинского значения вакцинации противоротавирусной вакциной в Украине}

\author{
С. А. Соловьев ${ }^{1}$, Дж. Роуз ${ }^{2}$, И. В. Дзюблик ${ }^{1}$, Е. П. Трохименко ${ }^{1}$ \\ ${ }^{1}$ Нацииональная медицинская академия последипломного образования имени П. Л. Шупика МЗ Украины, \\ кафедра вирусологии, г. Киев, ул. Дорогожицкая, 9, 04112, Украина \\ ${ }^{2}$ Case Western Reserve University, кафедра семейной медицины, отдел исследований, \\ Кливленд, Огайо, 44106, США
}

Представлены результаты расчетно-теоретических исследований, связанных с оценкой эффективности и медицинского значения вакцинации противоротавирусной вакциной в Украине. Искомые показатели - генотип-специфическая эффективность вакцины, число предотвращенных острых случаев заболевания, госпитализаций, амбулаторных визитов и смертей - получены применением математического моделирования и реализацией полученной модели на компьютере в виде дерева принятия решений на основе марковской модели. Результаты моделирования показали значительный положительный эффект вакцинации по сравнению с невакцинацией при учете достаточного охвата вакциной населения Украины.

Ключевые слова: ротавирусная инфекция, противоротавирусная вакцина, вакцинация, дерево принятия решений, марковская модель

Citation: Computer Research and Modeling, 2012, vol. 4, no. 2, pp. 407-421. 


\section{Introduction}

Acute intestinal infections (AII) are one of the most significant public health problems in the world. The spectrum of the pathogens which cause AII varied and includes pathogenic and pathogenic bacteria, protozoa and viruses. Among them rotavirus infection (RVI) plays a leading role in the structure of the viral diarrheal diseases among the infants and children under 5 years [Parashar, 2006; Soriano-Gabarro, 2006].

Often, children suffering from the rotavirus gastroenteritis (RVGE) require only outpatient care (medical consultation). However, in case of dehydration, emergency care or hospitalization and intravenous hydration are necessary. Each year worldwide the rotavirus causes approximately 111 million episodes of gastroenteritis that require only home care without GP consultation, 25 million cases result in the clinic visits and 2 millions children require hospitalization. By the age 5, 4 out of 5 children will have an episode of the rotavirus gastroenteritis, and while not every rotavirus infection (including the first infection) is symptomatic, 1 in 5 will visit a clinic and 1 in 65 will be hospitalized [Parashar, 2003]. The World Health Organization (WHO) estimates that 527,000 children under the age of five years die of rotavirus induced disease each year [Parashar, 2009]. Rotavirus gastroenteritis imposes a heavy economic burden, by incurring direct (consultation, emergency, hospitalization, medication) and indirect costs (parent work days lost, baby-sitting, additional diapers) [Grimwood, 2009; SorianoGabarro, 2006; World Health Organization, 2009].

A new vaccine, live attenuated human rotavirus vaccine with rotavirus strain RIX4414, based on a single frequently encountered strain of human rotavirus, has recently been licensed in 35 countries and the European Union [Glass, 2006]. The efficacy demonstrated in Latin American and European populations has been impressive [Ruiz-Palacios, 2005; Salinas, 2005; Vesikari, 2004], and many place a great hope in RIX4414 capacity to prevent deaths from dehydrating diarhoea. Currently, the rotavirus vaccine, based on the human rotavirus strain RIX4114 with genotype G1P[8], has been registered in Ukraine. The vaccination of children in the age from 6 months to 2 years with rotavirus vaccines (in closed children institutions to prevent gastroenteritis caused by rotavirus) is included into the National immunization schedule calendar of Ukraine, approved by the Order №595 of Ministry of Health of Ukraine from 16.09.2011 (Section. Recommended vaccinations) [The Ministry of Health of Ukraine, 2011]. However, there is an uncertainly on how the vaccine will be effective in Ukraine, where trials have not yet been completed.

Mathematical modeling - is a modern tool for predicting of the medical importance of the vaccination. It is based on the clinical and laboratory observations and molecular genetic monitoring of isolates of the rotaviruses. Mathematical modeling of the efficiency of the rotavirus vaccine is the object of our study.

\section{Methods of the research and modeling}

The virological and molecular genetic analysis were conduced for (1) 577 children with AII under 5 years old, which were treated in the pediatric ward of Kyiv Children's Clinical Infectious Diseases Hospital № 2, (2) 181 children from the Children's Hospital of Kyiv № 2, (3) 97 children from Lviv Children's Community Hospital of the Clinical Infectious Diseases, (4) 99 children from the Uman Children's hospital, (5) 70 children from the Odessa Regional Children's Hospital (70 children), (6) 100 children Sumy, (7) 100 children from Kharkiv. All the cases were recorded from 2006 to 2009. Presence of the antigens of the rotaviruses, noroviruses, astroviruses and adenoviruses in the clinical samples (feces) was determined by using (1) chromatographic analysis (ICA), (2) immune-enzyme analysis (ELISA), (3) rapid tests CitoTest Rota, (CerTest, Spain), (4) test kits Ridascreen ${ }^{\circledR E L I S A}$ (R-biopham, Germany) and (5) multiplex RT-PCR with hybridization-fluorescent detection of amplification products over the endpoint, using test kits AmpliSence ${ }^{\circledR R o t a v i r u s / N o r o v i r u s / A s t r o v i r u s-F L ~}$ (AmpliSence, The Central Research Institute of Epidemiology, Russian Federation). The genotypes of the rotaviruses in positive samples were identified by using the adapted version of the method of $[\mathrm{P}] \mathrm{G}$ 
genotyping of group A rotavirus with detection of amplification products in agarose gel, using test kits AmpliSense ${ }^{\circledR R}$ Rotavirus-Eph (AmpliSence, The Central Research Institute of Epidemiology, Russian Federation) [Подколзин, 2007].

Using the data distribution of the three subgroups of rotavirus strains in Ukraine as significant weight, for each of the case the expected efficacy against acute intestinal infections caused by rotavirus, (weight on scale Vesikari $>11$ ) was calculated. The analysis was also conducted separately for Kiev city and Odessa region, because of the high rates of migration in those regions.

Projecting the genotype-specific vaccine efficacy was made by using the methods of the multiplicative synthesis [Недашківська, 2005] and the distributive synthesis, which are used for this kind of calculation [Rose, 2008].

There were determined the respective shares of each subgroup in the general circulation of genotypes $\left(w^{C}=\left\{w_{j} \mid j=\overline{1,3}\right\}\right)$ as the normalized weight criteria. It was taken the degree of homology with respect to vaccine strains as a criterion. Effectiveness of vaccine against strains of a group of homology was obtained from the data of the clinical observations [Ruiz-Palacios, 2005], and tagged as $v_{j}$ - not normalized weight for criterion $C_{j}$.

For the method of distributive synthesis, or a linear convolution, the total efficacy is calculated by formula (1).

$$
w_{\text {distributive }}^{\text {sum }}=\sum_{j=1}^{N} w_{j}^{C} \cdot v_{j}, j=\overline{1, N}, N=3 .
$$

For the multiplicative method of the synthesis, or multiplicative convolution, the total efficacy is calculated by formula (2) to a weighted geometric mean.

$$
w_{\text {multiplicative }}^{\text {sum }}=\prod_{j=1}^{N}\left(v_{j}\right)^{w_{j}^{C}}, j=\overline{1, N}, N=3 \text {. }
$$

The above method for projecting setting-specific efficacy was validated using the data from a phase II trial of RIX4414, which occurred in Brazil, Venezuela and Mexico [Salinas, 2005].

The use of Markov processes in medicine was introduced by Beck and Pauker in 1983 [Beck, 1983; Sonnenberg, 1993], and today this approach, according to the electronic database of medical knowledge PubMed, is a powerful tool for solving the medical problems [PubMed].

Ways to describe a Markov random process, running in a system with discrete states, depends on at what moments of incidental time can occur transitions ("jumps") of the system from state to state.

A stochastic process is called process with discrete time, if the system transitions from state to state is possible only in well-defined, pre-fixed points in time: $t_{1}, t_{2}, \ldots$ etc. The intervals between these points system $\mathrm{S}$ save it state.

A stochastic process is called a process with continuous time, if the system's transition from state to state is possible in any, unknown in advance, occasional time t.

Let first consider a Markov random process with discrete states and discrete time. Let a system $\mathrm{S}$, which may be in the states $\mathrm{S}_{1}, \mathrm{~S}_{2}, \mathrm{~S}_{3}, \ldots, \mathrm{S}_{\mathrm{n}}$ and changes in the state of the system are possible only in the moments: $t_{1}, t_{2}, \ldots, t_{k}, \ldots$ These moments are called "steps" or "stages" of the process and consider a random process occurring in the system $\mathrm{S}$, as a function of integer arguments with step number $1,2, \ldots, \mathrm{k}, \ldots$.

Random process occurring in the system, is that at successive times $t_{1}, t_{2}, \ldots, t_{k}, \ldots$ system $S$ is in certain states, behaving, for example, as follows (in general, the system can not only change the state, but also to keep the old).

We shall denote $\mathrm{S}_{\mathrm{i}}{ }^{(\mathrm{k})}$ event consisting in the fact that after $\mathrm{k}$ steps the system is in $\mathrm{S}_{\mathrm{i}}{ }^{(\mathrm{k})}$ For any $\mathrm{k}$ events $\mathrm{S}_{1}{ }^{(\mathrm{k})}, \mathrm{S}_{2}{ }^{(\mathrm{k})}, \ldots, \mathrm{S}_{\mathrm{i}}{ }^{(\mathrm{k})}, \ldots, \mathrm{S}_{\mathrm{n}}{ }^{(\mathrm{k})}$ form a complete group and inconsistent. The process, which are occurring in the system can be represented as a sequence (chain) of the events, such as $\mathrm{S}_{1}{ }^{(0)}, \mathrm{S}_{2}{ }^{(1)}, \mathrm{S}_{1}{ }^{(2)}, \mathrm{S}_{4}{ }^{(3)} \ldots$. Such random sequence of the events is called Markov chain if for every step transition probability from any state $S_{i}$ in any $S_{j}$ does not depend on when and how the system came into the state $S_{i}$. 
Markov chain can be described using the state probabilities. Let at any given time (after any $\mathrm{k}^{\text {th }}$ step), the system $\mathrm{S}$ can be in one of the states $\mathrm{S}_{1}, \mathrm{~S}_{2}, \mathrm{~S}_{3}, \ldots, \mathrm{S}_{\mathrm{n}}$, i.e., realized one of the complete group of mutually incompatible events $\mathrm{S}_{1}{ }^{(\mathrm{k})}, \mathrm{S}_{2}{ }^{(\mathrm{k})}, \ldots, \mathrm{S}_{\mathrm{i}}{ }^{(\mathrm{k})}, \ldots, \mathrm{S}_{\mathrm{n}}{ }^{(\mathrm{k})}$.

We denote the probability of these events for the $\mathrm{k}^{\text {th }}$ step, through $\mathrm{p}_{1}(\mathrm{k})=\mathrm{p}\left(\mathrm{S}_{1}{ }^{(\mathrm{k})}\right)$, $\mathrm{p}_{2}(\mathrm{k})=\mathrm{p}\left(\mathrm{S}_{2}{ }^{(\mathrm{k})}\right), \ldots, \mathrm{p}_{\mathrm{i}}(\mathrm{k})=\mathrm{p}\left(\mathrm{S}_{\mathrm{i}}{ }^{(\mathrm{k})}\right), \ldots, \mathrm{p}_{\mathrm{n}}(\mathrm{k})=\mathrm{p}\left(\mathrm{S}_{\mathrm{n}}{ }^{(\mathrm{k})}\right)$.

For each step k:

$$
p_{1}(k)+p_{2}(k)+\ldots+p_{n}(k)=1 .
$$

As it is the probability of the mutually incompatible events, forming a complete group. Probabilities $\mathrm{p}_{1}(\mathrm{k}), \mathrm{p}_{2}(\mathrm{k}), \ldots, \mathrm{p}_{\mathrm{n}}(\mathrm{k})$ are called state probabilities.

Together, they form a vector:

$$
p^{(k)}=\left(p_{1}(k), p_{2}(k), \ldots, p_{n}(k)\right) .
$$

Random process (Markov chain) can be thought of as if the point representing the system S, randomly moving (wandering) in the graph states, and in our case in the decision tree, jumping from state to state in the moments $t_{1}, t_{2}, \ldots, t_{k}, \ldots$, and sometimes (in general), stopping at a certain number of steps in the same condition.

For each step (at time $t_{1}, t_{2}, \ldots, t_{k}, \ldots$ or number $1,2, \ldots, k, \ldots$ ) there is some probability of transition from any state to any other (some of them are equal to zero, if the direct transition in one step is not possible), as well as the likelihood of delay in this state. We call these probabilities are the transition probabilities of the Markov chain.

Consider a homogeneous Markov chain. We denote $\mathrm{P}_{\mathrm{ij}}$ probability of a transition in one step from state $S_{i}$ in state $S_{j}$. $P_{i i}$ will likely delay systems in the state $S_{i}$. The likelihood of the data can be presented in the form of a square matrix:

$$
P=P_{i j}=\left(\begin{array}{ccc}
P_{11} & \ldots & P_{1 n} \\
\vdots & \ddots & \vdots \\
P_{n 1} & \cdots & P_{n n}
\end{array}\right) .
$$

Some of the transition probabilities $\mathrm{P}_{\mathrm{ii}}$ may be zero, which means you can not transit from $\mathrm{i}^{\text {th }}$ to $\mathrm{j}^{\text {th }}$ state in one step. Along the main diagonal of the matrix of transition probabilities are likely $\mathrm{P}_{\mathrm{ii}}$ that the system is out of state $S_{i}$ and remain in it.

The sum of the terms in each row of the matrix (3) must be equal to unity, since no matter what state the system was not in front of the $\mathrm{k}^{\text {th }}$ step of the event $\mathrm{S}_{1}{ }^{(\mathrm{k})}, \mathrm{S}_{2}{ }^{(\mathrm{k})}, \ldots, \mathrm{S}_{\mathrm{i}}{ }^{(\mathrm{k})}, \ldots, \mathrm{S}_{\mathrm{n}}{ }^{(\mathrm{k})}$ are incompatible and form a complete group.

Having at our disposal the transition matrix, and knowing the initial state, we can find probabilities of the states $\mathrm{p}_{1}(\mathrm{k}), \mathrm{p}_{2}(\mathrm{k}), \ldots, \mathrm{p}_{\mathrm{n}}(\mathrm{k})$ after any $\mathrm{k}^{\text {th }}$ step.

According to the formula of total probability we obtain:

$$
p_{i}(k)=\sum_{j=1}^{n} p_{j}(k-1) P_{j i},(i=1, \ldots, n)
$$

or in matrix form:

$$
p_{i}^{(k)}=P^{T} \times p^{(k-1)} .
$$

Thus, the probabilities of the states $\mathrm{p}_{\mathrm{i}}(\mathrm{k})$ after the $\mathrm{k}^{\text {th }}$ step, defined by the recurrence relation (4) in terms of probabilities of the states after $(\mathrm{k}-1)^{\text {th }}$ step, and those in turn - through the state probabilities after $(\mathrm{k}-2)^{\text {th }}$ step, etc.

Analysis of the efficacy of the vaccination with rotavirus vaccine was provided using simulation methods. Evaluation was made with TreeAgePro 2009 (Williamstown, MA) (Fig. 1). 


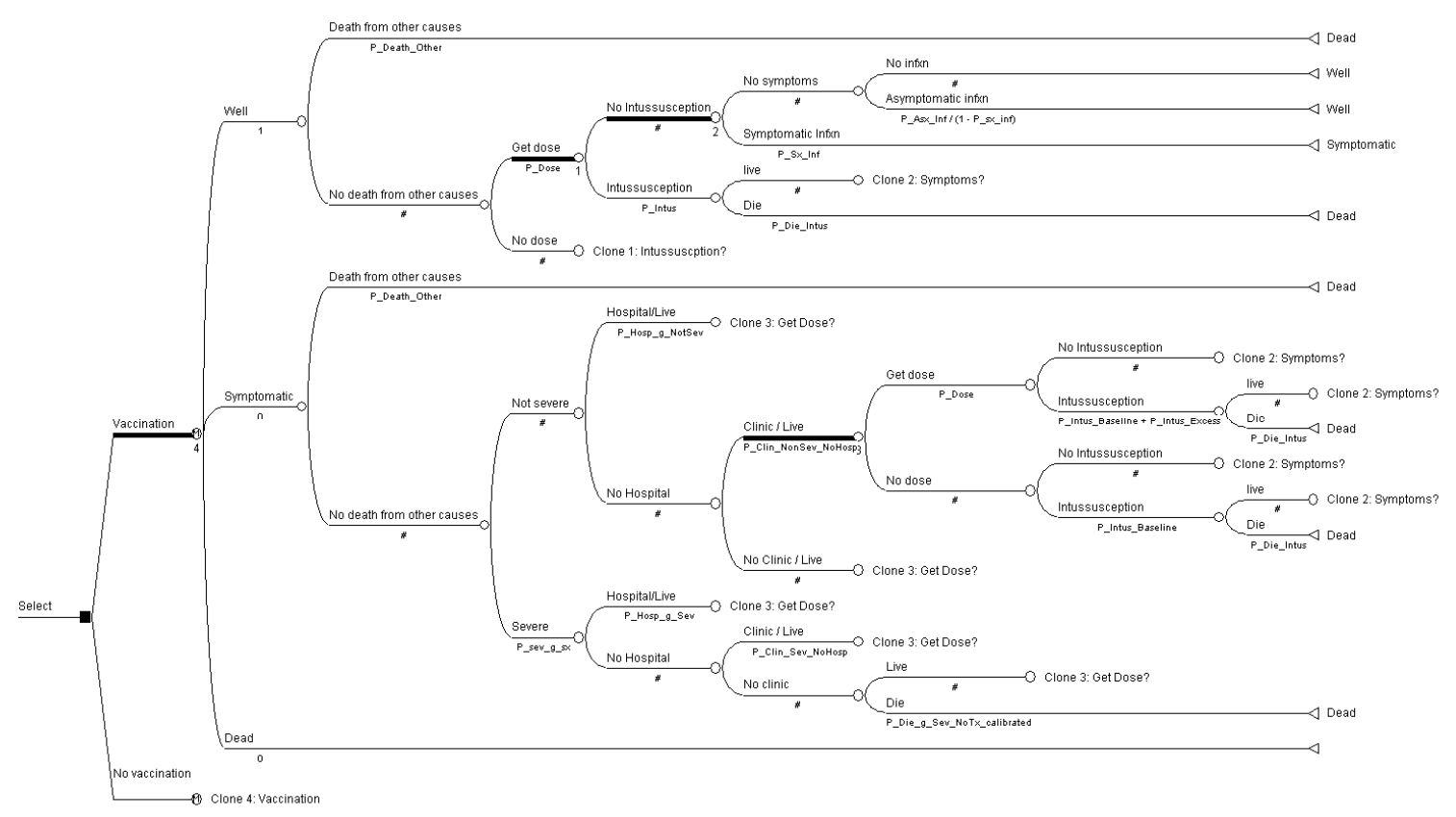

Fig. 1. Scheme of Markov model

Based on an analogue a model of decision making was build for children age group of five [Rose, 2009]. The model was develop on the parameters connected to the disease and vaccination with RIX4414 vaccine in recommended age of 2 and 4 months [Cortese, 2009]. The result was a "decision tree" - a scheme or algorithm, which predicts all variants of the disease. Building a "decision tree" was based on (1) identifying alternative approaches to a sick child, (2) describing successful and unsuccessful outcomes, and (3) assessment of the probability of their occurrence as a percentage. Then the data were analyzed based on Markov processes with Monte Carlo method to simulate a large number of random states of an individual child.

The model provides, that each individual begins life in the well state and thereafter resides in either the well, symptomatic, or dead state during each one month cycle for a total of 60 cycles. Individuals can receive doses of live attenuated human rotavirus vaccine at months two and four only. At the end of each cycle, each individual's risk for rotavirus infection is determined by number of vaccine doses received, time since receiving most recent dose, and number of previous rotavirus infections. If infected, individuals might develop symptoms in which case they will begin the next cycle in symptomatic state. In symptomatic state, gastroenteritis can be non-severe (Vesikari score $<11$ ) or severe (Vesikari score $\geq 11$ ) [Ruuska, 1990]. Symptom severity dictates probability that each individual will receive hospital care, outpatient care, or no formal treatment. Those with severe disease who receive no formal treatment are at risk for death. Each month, there is an age dependent background risk of death from non-rotavirus causes (not shown). (M) in circle represents Markov node; branches emanating from a Markov node represent possible states of being. Open circle represents chance node $\bullet$; branches emanating to right represent possible outcomes of probabilistic process. Left pointing triangle $\boldsymbol{4}$ designates terminal node; here, the state in which next cycle should begin is given. "Get dose" signifies contingency that individual receives dose of vaccine; "no dose" signifies that they do not receive.

Each possible chance event in the model was associated with an evidence based probability and the exact sequence and timing of events experienced by a given individual were the results of random number draws occurring at each juncture of the model. We aggregated the experience of 100000 simulated individuals to predict the expected number of rotavirus infections (up to three per individual); their severity; the number of admissions to hospital, clinic visits, and home treatments for rotavirus gastroenteritis; the total cost of rotavirus related use; and the number of rotavirus related deaths under two different strategies: universal vaccination with RIX4414 at the recommended ages of 2 and 4 months [20] versus no vaccination (the status quo). 


\section{Parameters of modeling}

\section{Incidence, morbidity, and mortality}

Rates of the rotavirus infections are similar worldwide [Parashar, 2003]. Accordingly, we chose the base parameters related to infection risk on a rigorous prospective study of rotavirus incidence in a cohort of 200 Mexican infants followed from birth to 24 months of age [Velazquez, 1996]. Authors closely monitored children for rotavirus infection with serial stool assays and serum immunoassays. Investigators recorded the time to first and subsequent infections and the severity of each infection (including asymptomatic) for each individual during follow-up. Based on the reported cumulative incidence of the $\mathrm{n}^{\text {th }}$ infection at $6^{\text {th }}, 12^{\text {th }}$, and $24^{\text {th }}$ month intervals (table 1 ), we calculated one month hazard rates and converted these to one month transition probabilities corresponding to the appropriate age interval and number of previous infections. Hazard rates for the $12^{\text {th }}$ to $24^{\text {th }}$ month interval formed the basis for transition probability estimates for the $\mathrm{n}^{\text {th }}$ infection after the $24^{\text {th }}$ cycle. Data from the same cohort also served as the basis for estimates of probabilities that those infected would experience no symptoms, non-severe symptoms, or severe symptoms with first to the third infections. Severity (or lack) of symptoms did not influence the degree of natural protection conferred against subsequent rotavirus re-infection [Angel, 2007].

Table 1. Disease related parameters

\begin{tabular}{|c|c|c|c|}
\hline Parameter & Value & Range & $\begin{array}{c}\text { Source/ } \\
\text { comments }\end{array}$ \\
\hline \multicolumn{4}{|c|}{ Cumulative incidence of $\mathrm{n}^{\text {th }}$ infection by 6,12 , and 24 months*: } \\
\hline First infection & 0,$34 ; 0,67 ; 0,96^{* *}$ & \multirow{5}{*}{$\begin{array}{l}\text { Calculated } \\
\text { transition } \\
\text { probabilities } \\
\text { varied } \\
\quad \pm 50 \%\end{array}$} & \multirow{5}{*}{$\begin{array}{l}\text { [Velazquez, } \\
\text { 1996] }\end{array}$} \\
\hline Second infection & 0,$04 ; 0,30 ; 0,69$ & & \\
\hline Third infection & 0,$00 ; 0,07 ; 0,42$ & & \\
\hline $\begin{array}{l}\text { Probability that } 1 \mathrm{st}, 2 \mathrm{nd} \text {, and } 3 \mathrm{rd} \text { infec- } \\
\text { tions, respectively, will cause symptoms }\end{array}$ & 0,$47 ; 0,32 ; 0,25$ & & \\
\hline $\begin{array}{l}\text { Probability that symptoms, if present, will } \\
\text { be severe (1st, 2nd, 3rd infections)*** }\end{array}$ & 0,$28 ; 0,19 ; 0,00$ & & \\
\hline $\begin{array}{l}\text { Probability of hospitalization with severe } \\
\text { rotavirus disease }\end{array}$ & 0,0181 & $\pm 50 \%$ & $\begin{array}{l}\text { [Ogilvie, 2011; } \\
\text { Крамарев, 2007; } \\
\text { Шунько, 2011] }\end{array}$ \\
\hline $\begin{array}{l}\text { Probability of clinical visit with severe } \\
\text { rotavirus disease }\end{array}$ & 0,145 & $\pm 50 \%$ & $\begin{array}{c}\text { Based on } \\
\text { [Parashar, 2003] }\end{array}$ \\
\hline $\begin{array}{l}\text { Probability of dying from severe rotavirus } \\
\text { disease }\end{array}$ & 0,00005 & $\pm 50 \%$ & [Ogilvie, 2011] \\
\hline $\begin{array}{l}\text { Probability of dying from severe rotavirus } \\
\text { disease without formal medical attention }\end{array}$ & 0,0002 & $\pm 50 \%$ & $\begin{array}{l}\text { Calibrated to } \\
\text { yield known five } \\
\text { year rotavirus } \\
\text { mortality [Ogil- } \\
\text { vie, 2011] }\end{array}$ \\
\hline
\end{tabular}

*Hazard rate based on $r=-\ln (1-p) / t_{1}$ where $t_{1}=$ length of interval (for example, 6 months between 6 th and $12^{\text {th }}$ months of life) and $p=$ probability of infection $\mathrm{n}$ by end of interval given being at risk for infection $\mathrm{n}$ at beginning of interval, transition probability calculated from hazard rate as $\mathrm{p}=1-\mathrm{e}-\mathrm{rt}_{2}$ where $\mathrm{t}_{2}=$ cycle length (one month for present model).

**Based on observation that infections by pathogenic rotavirus strains in first few months of life are rare, we set probability of infection before 2 months of age to 0 .

$* * *$ Severe infections are defined as those with Vesikari score $\geq 11$.

During estimation it was given the probability of death from rotavirus infection -0.00005 according to research in Eastern and Central Europe [Ogilvie, 2011]. In accordance with this, model by calibration found the probability of death from severe rotavirus infection without medical care 0.0002. Probability of hospitalization with AII in Ukraine is 0.02 [Крамарев, 2007]. Among those, the probability of hospitalization with RVI is 0.905 [Шунько, 2011], according to our clinical studies. Therefore, the probability of hospitalization with RVI among the children under five years: $0.02 \cdot 0.905=0.0181$, which is comparable to the studies in Eastern and Central Europe (0.01-0.02) 
[Ogilvie, 2011]. According to Parashar UD et al. [Parashar, 2003] for each case of hospitalization it is accounted 8 outpatient visits, so the probability of outpatient visits at the RVI under five years is $0.0181 \cdot 8=0.145$. At each cycle, all persons have dependent on age probability of death from causes unrelated to RVI, based on the life tables for Ukraine [WHO. World Health Statistics, 2011].

\section{Vaccine characteristics}

We assumed that coverage rates for doses one and two of the vaccine would match rates for doses one and three of the diphtheria-tetanus-pertussis vaccine in Ukraine (given on the same schedule as RIX4414) (Table 2) [WHO. Immunization profile - Ukraine, 2008]. Using a previously described technique, we estimated setting specific efficacy based on serotype specific efficacy data.

Table 2. Vaccine related parameters

\begin{tabular}{|c|c|c|c|}
\hline Parameters & Value & Range & $\begin{array}{c}\text { Source/ } \\
\text { comments }\end{array}$ \\
\hline Coverage for dose 1 (age 2 months) & 0.73 & $0.36-1.0$ & $\begin{array}{l}\text { Based on DPT-1 } \\
\text { vaccine coverage } \\
\text { [WHO. Immuniza- } \\
\text { tion profile - } \\
\text { Ukraine, 2008] } \\
\end{array}$ \\
\hline Coverage for dose 2 (age 4 months) & 0.90 & $0.45-1.0$ & $\begin{array}{l}\text { Based on DPT-3 } \\
\text { vaccine coverage } \\
\text { [WHO. Immuniza- } \\
\text { tion profile - } \\
\text { Ukraine, 2008] }\end{array}$ \\
\hline \multicolumn{4}{|c|}{ Efficacy against severe infection caused by rotavirus strains with: } \\
\hline $\mathrm{G}$ and $\mathrm{P}$ proteins in common with RIX4414 & 0.908 & $0.705-0.982$ & \multirow{3}{*}{$\begin{array}{l}\text { [Ruiz-Palacios, } \\
\quad 2006]\end{array}$} \\
\hline Either G or P in common with RIX4414 & 0.869 & $0.628-0.966$ & \\
\hline Neither G nor P in common with RIX4414 & 0.714 & $0.201-0.911$ & \\
\hline $\begin{array}{l}\text { Ratio of efficacy against any symptomatic rotavi- } \\
\text { rus infection to efficacy against severe infection }\end{array}$ & 0.873 & $0.773-0.973$ & [Vesikari, 2004] \\
\hline $\begin{array}{l}\text { Ratio of efficacy against asymptomatic infection } \\
\text { to efficacy against severe infection }\end{array}$ & 0.437 & $0.377-0.537$ & [Velazquez, 1996] \\
\hline $\begin{array}{l}\text { Proportion of full efficacy conferred by single } \\
\text { dose }\end{array}$ & 0.625 & $0.425-0.825$ & [Lopez, 2006] \\
\hline $\begin{array}{l}\text { Assumed annual rate of waning in vaccine effica- } \\
\text { cy }\end{array}$ & 0.049 & $0.245-0.735$ & $\begin{array}{l}\text { Based on decline in } \\
\text { efficacy between } 1^{\text {st }} \\
\text { and } 2 \text { nd seasons in } \\
\text { two year trial in } \\
\text { Latin America } \\
\text { [Linhares, 2008] }\end{array}$ \\
\hline \multicolumn{4}{|c|}{ Prevalence of rotavirus strains with: } \\
\hline $\mathrm{G}$ and $\mathrm{P}$ proteins in common with RIX4414 & 0.33 & \multirow{3}{*}{-} & \multirow{3}{*}{$\begin{array}{l}\text { Based on own epi- } \\
\text { demiological stu- } \\
\text { dies [Solovyov, } \\
\text { 2011] }\end{array}$} \\
\hline Either $\mathrm{G}$ or P in common with RIX4414 & 0.51 & & \\
\hline Neither G nor P in common with RIX4414 & 0.16 & & \\
\hline
\end{tabular}


In the absence of analogous serotype specific data from trials needed to estimate efficacy against any rotavirus symptoms, we estimated this value by adjusting our projected efficacy against severe disease by the ratio of overall efficacy against any symptomatic infection to overall efficacy against severe infection from a recent phase III trial [Vesikari, 2004]. Similarly, to estimate the vaccine's efficacy against asymptomatic infection, we adjusted the projected vaccine efficacy against severe infection by the ratio of efficacy against asymptomatic to severe infection reportedly conferred by the first naturally acquired rotavirus infection [Velazquez, 1996].

We considered the efficacy of a single dose of RIX 4414 to be $37.5 \%$ lower than that of a full two dose course [Lopez, 2006]. The annual rate of waning of efficacy was based on the differential between the first and second season efficacy in a large Latin American trial and converted into monthly rates for our model [Linhares, 2008]. In our study, we use the parameter range within $\pm 50 \%$ of baseline value.

We assumed no risk of serious adverse events for those receiving the vaccine. The combined clinical trial and post-marketing data pertaining to RIX4414 suggest no increased rates of adverse events, including intussusception [Global Advisory Committee on Vaccine Safety, 2008].

\section{Results and discussion}

As a result of genotyping of the selected 210 positive samples (2006-2009), P-genotypes were detected in 176 cases $(83.8 \%)$, G-genotypes $(86.6 \%)$ - in 182 cases. P-genotype was not detected in $3.3 \%$ of the cases, G-genotype - in $4.3 \%$, and both $\mathrm{P} / \mathrm{G}$ genotypes were not detected in $5.7 \%$ of all cases (table 3-5). The overall structure of the distribution of the different genotypes in Ukraine is presented in fig. 2 .

Table 3. G/P-genotypes of rotaviruses group A isolated with multiplexed PCR in Kyiv city in the clinical material of children with acute diarrhea $(\mathrm{N}=100)$

\begin{tabular}{|c|c|c|c|c|c|c|c|c|c|}
\hline \multirow[b]{2}{*}{$\begin{array}{l}\text { P-genotypes, } \\
\quad \% \pm \mathrm{SE} \%\end{array}$} & \multicolumn{8}{|c|}{ G-genotypes, $\% \pm \mathrm{SE} \%$} & \multirow{2}{*}{ 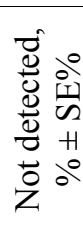 } \\
\hline & $\bar{\Xi}$ & $\widetilde{\mho}$ & $\Theta$ & ৫ & i & $\frac{\mho}{ \pm}$ & $\begin{array}{l}\mathcal{U} \\
+ \\
0\end{array}$ & 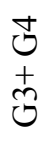 & \\
\hline $\mathrm{P}[4]$ & 0 & $8.5 \pm 2.80$ & 0 & 0 & 0 & 0 & 0 & 0 & 0 \\
\hline $\mathrm{P}[8]$ & $21 \pm 4.09$ & 0 & $12.5 \pm 3.32$ & $52.0 \pm 5.02$ & $6.0 \pm 2.39$ & 0 & 0 & 0 & 0 \\
\hline $\begin{array}{l}\text { Not detected, } \\
\% \pm \mathrm{SE} \%\end{array}$ & 0 & 0 & 0 & 0 & 0 & 0 & 0 & 0 & 0 \\
\hline
\end{tabular}

Table 4. G/P-genotypes of rotaviruses group A isolated with multiplexed PCR in Odessa region in the clinical material of children with acute diarrhea $(\mathrm{N}=70)$

\begin{tabular}{|c|c|c|c|c|c|c|c|c|c|}
\hline \multirow[b]{2}{*}{$\begin{array}{c}\text { P-genotypes, } \\
\% \pm \mathrm{SE} \%\end{array}$} & \multicolumn{8}{|c|}{ G-genotypes, $\% \pm \mathrm{SE} \%$} & \multirow{2}{*}{ 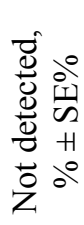 } \\
\hline & $\bar{\sigma}$ & $\mho$ & $\mho$ & オ & Ð) & $\frac{\mathfrak{J}}{\Xi}$ & $\begin{array}{l}\mathcal{O} \\
\pm \\
0\end{array}$ & 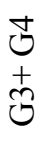 & \\
\hline $\mathrm{P}[4]$ & 0 & $20,0 \pm 4,82$ & 0 & 0 & 0 & 0 & 0 & 0 & 0 \\
\hline $\mathrm{P}[8]$ & $49.0 \pm 6.02$ & 0 & $5.5 \pm 2.74$ & $9.0 \pm 3.44$ & $2.5 \pm 1.9$ & $1.0 \pm 1.0$ & 0 & 0 & 0 \\
\hline $\begin{array}{l}\text { Not detected, } \\
\% \pm \mathrm{SE} \%\end{array}$ & 0 & 0 & 0 & 0 & 0 & 0 & 0 & 0 & 0 \\
\hline
\end{tabular}


Table 5. G/P-genotypes of rotaviruses group A isolated with multiplexed PCR in Ukraine in the clinical material of children with acute diarrhea $(\mathrm{N}=210)$

\begin{tabular}{|c|c|c|c|c|c|c|c|c|c|}
\hline \multirow{2}{*}{$\begin{array}{l}\text { P-genotypes, } \\
\quad \% \pm \mathrm{SE} \%\end{array}$} & \multicolumn{8}{|c|}{ G-genotypes, $\% \pm \mathrm{SE} \%$} & \multirow{2}{*}{ 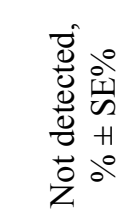 } \\
\hline & $\bar{U}$ & $\mho$ & $\Theta$ & ঠ & ல & $\begin{array}{l}0 \\
\pm \\
0\end{array}$ & $\begin{array}{l}0 \\
\pm \\
\Xi\end{array}$ & $\begin{array}{l}0 \\
+ \\
0\end{array}$ & \\
\hline $\mathrm{P}[4]$ & 0 & $18,09 \pm 2,49$ & 0 & 0 & 0 & 0 & 0 & 0 & 0 \\
\hline $\mathrm{P}[8]$ & $32.8 \pm 3.25$ & $2.85 \pm 1.15$ & $10.5 \pm 2.1$ & $20 \pm 2.77$ & $0.95 \pm 0.67$ & $2 \pm 0.97$ & $2 \pm 0.97$ & $0.47 \pm 0.5$ & $3.2 \pm 1.2$ \\
\hline $\begin{array}{l}\text { Not detected, } \\
\quad \% \pm \mathrm{SE} \%\end{array}$ & $2.38 \pm 1.05$ & $1.43 \pm 0.82$ & 0 & $0.47 \pm 0.47$ & 0 & 0 & 0 & 0 & $5.71 \pm 1.6$ \\
\hline
\end{tabular}

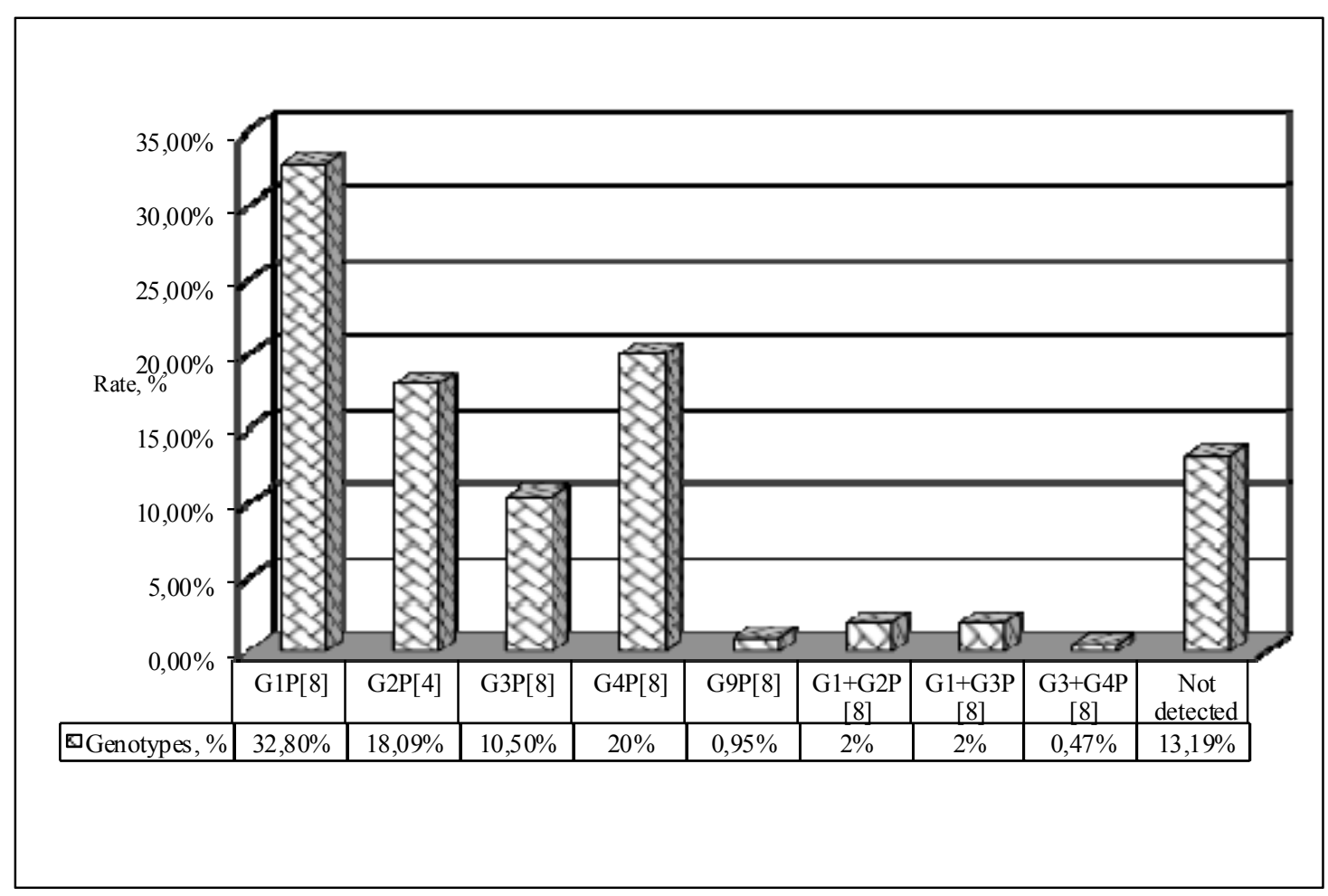

Fig. 2. The structure of the genotypes distribution in Ukraine

Also we investigated the circulation of the rotaviruses in Kyiv and Odessa Region, as the most densely populated areas with high migration rates. The results of the study are shown in fig. 3.

A recent phase III trial of LA-HRV in infants from 11 Latin American countries and Finland [Ruiz-Palacios, 2006] provided separate figures for the efficacy of the vaccine against severe disease caused by three subsets of the infecting rotavirus strains isolated from subjects' stool specimens: G1P[8]; G3P[8], G4P[8], G9P[8]; G2P[4]. These subsets correspond to different degrees of homology with the G1P[8] vaccine strain: homologous to both antigenic proteins ( $\mathrm{G}$ and $\mathrm{P}$ ), homologous to only one, or homologous to neither. We calculated the proportion of strains observed in Ukraine that fell into each of these three homology-based categories according to data from an epidemiological survey. Using the proportions of strains in each of these three categories as weights and the three different strain-specific efficacy figures from the phase III trial (fig. 4), we calculated an expected efficacy against severe rotavirus disease in Ukraine. 


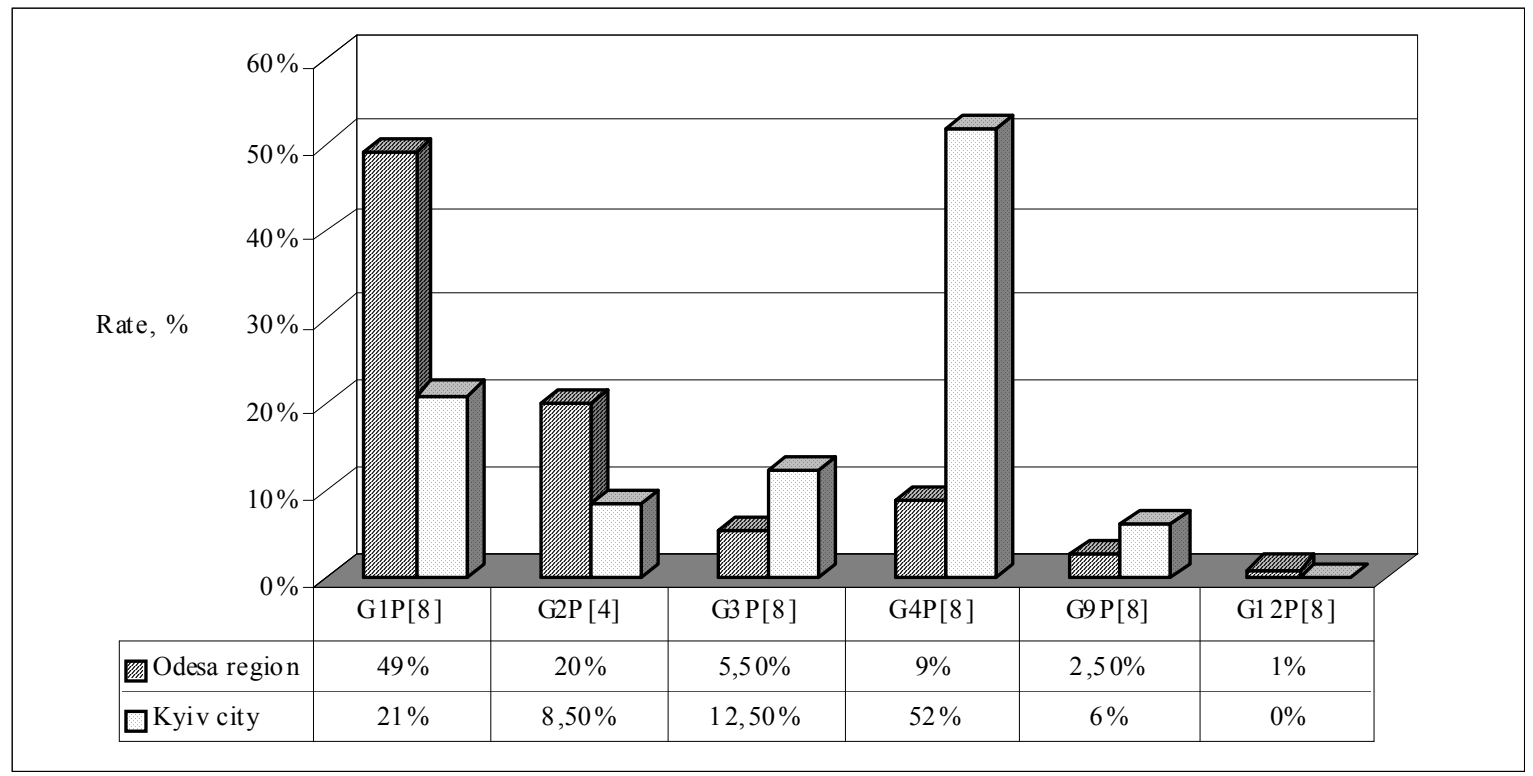

Fig. 3. The structure of the genotypes distribution in Kyiv city and Odessa Region

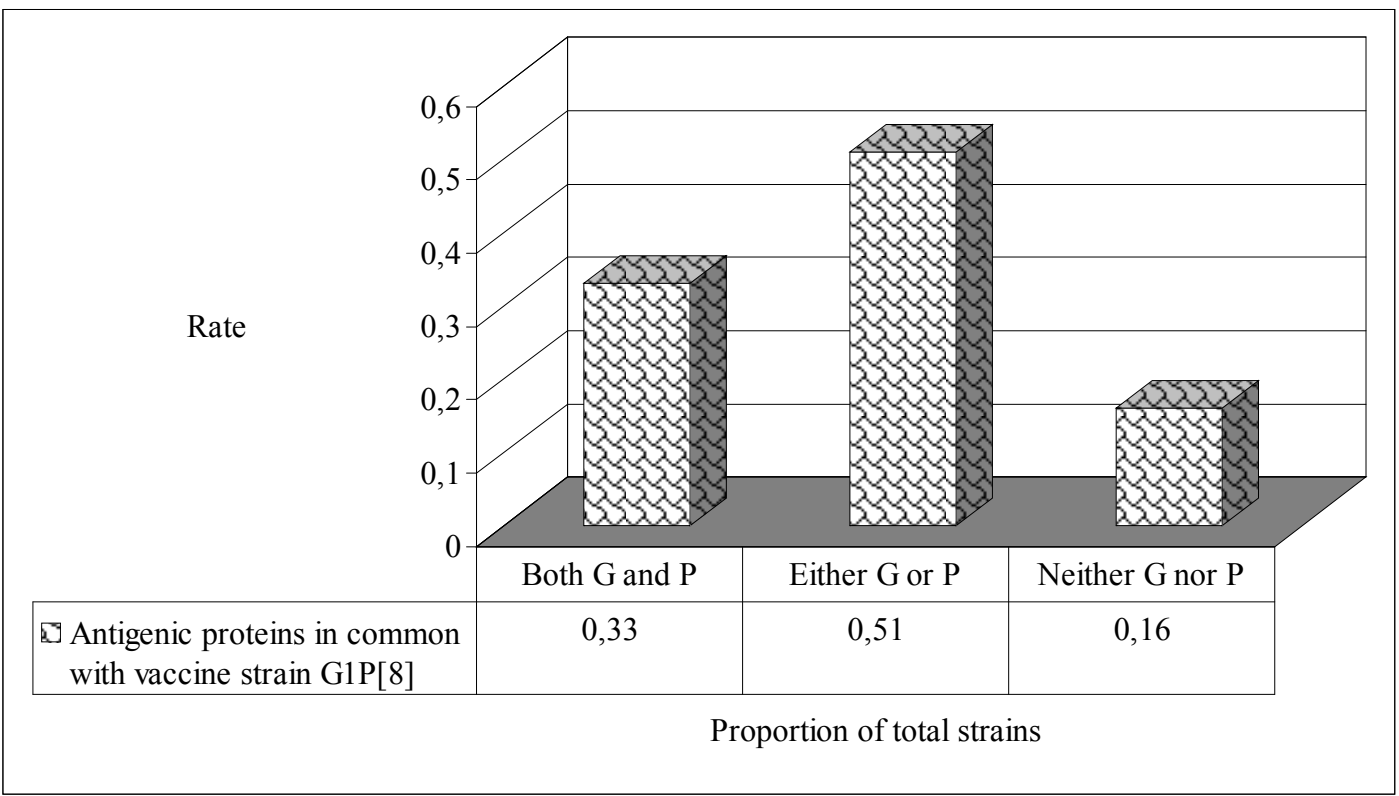

Fig. 4. Shares of the groups of the rotaviruses with certain homology to vaccine strain RIX4114

As it is shown in table 6, the projected efficacy for Ukraine was 0.812 (according to distributive synthesis) and 0.795 (according to multiplicative synthesis). The average value of theoretically calculated genotype-specific vaccine efficacy is 0.804 , i. e. in case of its application in Ukraine, the number of severe cases of rotavirus infection among young children will decrease by $80,4 \%$. This result is comparable to the overall efficacy against severe disease of 0.847 (95\% CI: $0.717-0.924)$ from the phase III trial in Latin American and Finnish infants [Ruiz-Palacios, 2006; Vesikari, 2004].

To establish lower and upper bounds for sensitivity analysis of vaccine efficacy, we used the above method but altered our figures for strain prevalence to reflect a worst-case and a best-case scenario. To model the worst-case strain distribution for Ukraine, we determined which of two regions, Kyiv or Odessa Region, for which we had the strain data, according to its homology to vaccine strain (fig. 5), had the lowest proportion of the doubly homologous G1P[8] strain, then assumed that the entire country was characterized by this low proportion of G1P[8]. 
Table 6. Expected efficacy of live attenuated human rotavirus vaccine against severe rotavirus disease based on viral strain distributions observed in Ukraine

\begin{tabular}{|c|c|c|c|c|}
\hline \multirow{2}{*}{$\begin{array}{c}\text { Antigenic proteins in com- } \\
\text { mon with vaccine strain } \\
\text { G1P[8] } \\
\text { Both G and P }\end{array}$} & $\begin{array}{c}\text { Proportion of } \\
\text { total strains, } w_{j}\end{array}$ & $\begin{array}{c}\text { Strain-specific vaccine } \\
\text { efficacy [Ruiz-Palacios, } \\
2006], v_{j}\end{array}$ & $\begin{array}{c}\text { Result } \\
\text { distributive } \\
\text { synthesis } \\
w_{j}^{C} \cdot v_{j}\end{array}$ & $\begin{array}{c}\text { multiplicative } \\
\text { synthesis } \\
\left(v_{j}\right)^{w_{j}^{c}}\end{array}$ \\
\hline Either G or P & 0.33 & 0.908 & 0.3 & 0.969 \\
\hline Neither G nor P & 0.51 & 0.869 & 0.44 & 0.931 \\
\hline Both G and P & 0.16 & 0.454 & 0.072 & 0.881 \\
\hline \multirow{2}{*}{ Overall mean efficacy } & & & $\Sigma=0.812$ & $\Pi=0.795$ \\
\hline
\end{tabular}

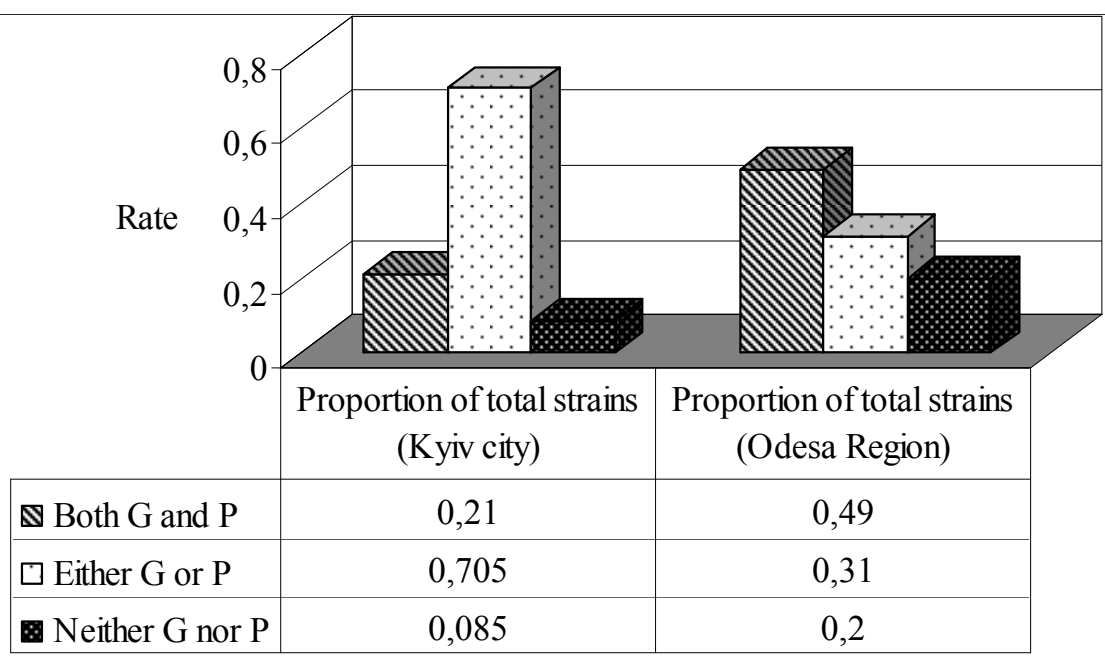

Fig. 5. Shares of the groups of the rotaviruses with certain homology to vaccine strain RIX4114 in Kyiv city and Odessa Region

Similarly, we determined which region had the lowest proportion of strains homologous to G1 and $\mathrm{P}[8]$, then assumed the entire country had that proportion of singly homologous strains. Finally, we determined which region had the highest proportion of strains homologous to neither G1 nor P[8] and assumed the entire country was characterized by this high prevalence of non-homologous strains. Using an analogous approach, we estimated the best-case efficacy based on strain prevalence in the three cities with the highest proportion of doubly homologous strains, the highest proportion of singly homologous strains and the lowest proportion of non-homologous strains. According to the data, normalized to $100 \%$, with worst and best scenarios, the average predictive efficacy is 0.750 and 0.852 , respectively. Note that these data are included in the confidence interval range of vaccine efficacy, which was calculated in clinical trials (95\% CI: 0.717-0.924) (table 7-8). 
Table 7. Expected efficacy of live attenuated human rotavirus vaccine against severe rotavirus disease based on viral strain distributions observed in Ukraine (worst-case scenario)

\begin{tabular}{|c|c|c|c|c|c|}
\hline \multirow[b]{2}{*}{$\begin{array}{l}\text { Antigenic proteins in } \\
\text { common with vaccine } \\
\text { strain G1P[8] } \\
\text { Both G and P }\end{array}$} & \multirow[b]{2}{*}{$\begin{array}{l}\text { Proportion of total } \\
\text { strains (worst-case } \\
\text { scenario), } w_{j}\end{array}$} & \multirow[b]{2}{*}{$\begin{array}{c}\text { Normalized } \\
\text { data, } w_{j}\end{array}$} & \multirow[b]{2}{*}{$\begin{array}{c}\text { Strain-specific } \\
\text { vaccine efficacy } \\
\text { [Ruiz-Palacios, } \\
\text { 2006], } v_{j}\end{array}$} & \multicolumn{2}{|c|}{ Result } \\
\hline & & & & $\begin{array}{c}\text { distributive } \\
\text { synthesis } \\
w_{j}^{C} \cdot v_{j}\end{array}$ & $\begin{array}{l}\text { multiplicative } \\
\text { synthesis } \\
\left(v_{j}\right)^{w_{j}^{c}}\end{array}$ \\
\hline Either $\mathrm{G}$ or $\mathrm{P}$ & 0.21 & 0.292 & 0.908 & 0.265 & 0.972 \\
\hline Neither $G$ nor $P$ & 0.31 & 0.431 & 0.869 & 0.375 & 0.941 \\
\hline Both $\mathrm{G}$ and $\mathrm{P}$ & 0.2 & 0.278 & 0.454 & 0.126 & 0.803 \\
\hline \multirow{2}{*}{\multicolumn{4}{|c|}{ Overall mean efficacy }} & $\Sigma=0.766$ & $\Pi=0.735$ \\
\hline & & & & \multicolumn{2}{|c|}{ Mean $=0.750$} \\
\hline
\end{tabular}

Table 8. Expected efficacy of live attenuated human rotavirus vaccine (LA-HRV) against severe rotavirus disease based on viral strain distributions observed in Ukraine (best-case scenario)

\begin{tabular}{|c|c|c|c|c|c|}
\hline $\begin{array}{c}\text { Antigenic proteins in } \\
\text { common with vaccine } \\
\text { strain G1P[8] } \\
\text { Both G and P }\end{array}$ & $\begin{array}{c}\text { Proportion of } \\
\text { total strains } \\
\text { (best-case sce- } \\
\text { nario), } w_{j}\end{array}$ & $\begin{array}{c}\text { Normalized } \\
\text { data, } w_{j}\end{array}$ & $\begin{array}{c}\text { Strain-specific } \\
\text { vaccine efficacy } \\
\text { Ruiz-Palacios, } \\
2006], v_{j}\end{array}$ & $\begin{array}{c}\text { distributive } \\
\text { synthesis } \\
w_{j}^{C} \cdot v_{j}\end{array}$ & $\begin{array}{c}\text { multiplicative } \\
\text { synthesis } \\
\left(v_{j}\right)^{w_{j}^{c}}\end{array}$ \\
\hline Either G or P & 0.49 & 0.383 & 0.908 & 0.348 & 0.964 \\
\hline Neither G nor P & 0.705 & 0.551 & 0.869 & 0.479 & 0.926 \\
\hline Both G and P & 0.085 & 0.066 & 0.454 & 0.03 & 0.949 \\
\hline \multicolumn{2}{|c|}{ Overall mean efficacy } & & $\sum=0.857$ & $\Pi=0.847$ \\
\cline { 3 - 6 } & & & Mean $=0.852$ \\
\hline
\end{tabular}

By using the simulation of Markov model (both strategies) we prognoses the number of the clinical events and expected needed medical intervention among the children under five years and one year. In the baseline scenario (with the level of vaccine coverage $\sim 140000$ doses) we observed a significant positive effect of the vaccination: reduction in number of hospitalizations, outpatient visits and infections with severe disease (table 9).

Table 9. Expected clinical events and use of health services related to rotavirus infection in birth cohort of 100000 children followed for five years under strategies of no vaccination and vaccination with RIX4414 (baseline scenario)

\begin{tabular}{|l|c|c|c|}
\hline & No vaccination & Vaccination & Change (\%) \\
\hline & Clinical events per 100 000 children (SE = 0.3\%) & 265440 & $8.8 \%$ \\
\hline Any infection & 291170 & 194034 & $2.1 \%$ \\
\hline Asymptomatic infections & 190059 & 71406 & $29.4 \%$ \\
\hline Symptomatic infections & 101111 & 11827 & $37.4 \%$ \\
\hline Severe infections & 18900 & 2 & $60 \%$ \\
\hline Deaths & 5 & 59549 & $29.4 \%$ \\
\hline \multicolumn{2}{|c|}{ Use of health services per 100 000 children (SE = 0.3\%) } \\
\hline Home treatment & 84341 & 9263 & $28.3 \%$ \\
\hline Outpatient visits & 12918 & 2266 & $38.3 \%$ \\
\hline Admissions to hospital & 3673 & & \\
\hline
\end{tabular}

Table 6 shows the projected numbers of the clinical events and use of health services per 100000 children followed for five years under both strategies. It is expected that each year vaccination would prevent $37.4 \%$ severe episodes of gastroenteritis, $28.3 \%$ outpatient visits, $38.3 \%$ admissions to hospital, and $60 \%$ deaths among children younger than 5 years.

Since the model is largely dependent on the level of vaccine coverage of child population, the question arises on the effect of vaccination with changing of this parameter. Thus it was decided to 
evaluate the effect of vaccination with a decrease in vaccine coverage of $50 \%$ from baseline scenario (table 10).

Table 10. Expected clinical events and use of health services related to rotavirus infection in birth cohort of 100000 children followed for five years under strategies of no vaccination and vaccination with RIX4414 (reduced level of vaccine coverage from baseline scenario)

\begin{tabular}{|c|c|c|c|}
\hline & No vaccination & Vaccination & Change (\%) \\
\hline \multicolumn{4}{|c|}{ Clinical events per 100000 children $(\mathrm{SE}=0.3 \%)$} \\
\hline Any infection & 291170 & 281872 & $3.2 \%$ \\
\hline Asymptomatic infections & 190059 & 192273 & $1.2 \%$ \\
\hline Symptomatic infections & 101111 & 89599 & $11.4 \%$ \\
\hline Severe infections & 18900 & 16084 & $14.9 \%$ \\
\hline Deaths & 5 & 3 & $40 \%$ \\
\hline \multicolumn{4}{|c|}{ Use of health services per 100000 children $(\mathrm{SE}=0.3 \%)$} \\
\hline Home treatment & 84341 & 74702 & $11.4 \%$ \\
\hline Outpatient visits & 12918 & 11525 & $10.8 \%$ \\
\hline Admissions to hospital & 3673 & 3128 & $14.8 \%$ \\
\hline
\end{tabular}

Simulation results show that the reduction of $50 \%$ from base case scenario is a critical vaccine coverage ( $\sim 53000$ doses), and the level of coverage less than $50 \%$ of the cover DPT-1/3 vaccines leads to the fact that the medical effect of vaccination will be almost null.

This study suggests that universal RIX4414 vaccination in Ukraine would prevent $40 \%$ of the letal cases associated with RVI. In the base case analysis, we projected that vaccination would prevent annually: $37.4 \%$ severe episodes of gastroenteritis, $28.3 \%$ outpatient visits, $38.3 \%$ admissions to hospital, and $60 \%$ deaths from RVI among children younger than 5 years. In a case of $50 \%$ coverage with vaccination, the projected figures are significantly low. Therefore, the projected effect of the vaccination was heavily influenced by the changes in levels of vaccine coverage and vaccine efficacy.

\section{Conclusion}

Predictive model of the genotype-specific efficacy of rotavirus vaccine based on strain RIX4114 with genotype G1P[8] in Ukraine was designed using a fundamentally new analytical methods. Based on the molecular genetic studies, it was shown that in case of the use of vaccine in Ukraine, the number of severe cases of rotavirus infection among infants will be reduced by $80.4 \%$.

The medical value of rotavirus infection in Ukraine was evaluated and possible effects of vaccination among children under five years was predicted on the basis of decision tree and Markov model. The results showed that the effect is significant: significantly fewer hospitalizations, outpatient visits, infection with severe disease. It was shown that vaccination would be meaningful only in case of high coverage of children in the Ukraine - at the level of DPT-1 and DPT-3 vaccine coverage.

\section{References}

Angel J., Franco M. A., Greenberg H. B. Rotavirus vaccines: recent developments and future considerations. Nat. Rev. Microbiol. 2007; 5: pp. 529-539.

Beck J. R., Pauker S. G. The Markov process in medical prognosis. Med Decis Making 3: pp. 419-458. 1983.

Cortese M. M., Parashar U.D. Prevention of rotavirus gastroenteritis among infants and children: recommendations of the advisory committee on immunization practices (ACIP). MMWR Recomm Rep 2009; 58: pp. 1-25.

Glass R., Parashar U., Bresee J., et al. Rotavirus vaccines: current prospects and future challenges. Lancet 2006 Jul 22; 368: pp. 323-32. 
Global Advisory Committee on Vaccine Safety, 17-18 December 2008. Wkly Epidemiol Rec 2009; 84: pp. 37-40.

Grimwood K., Lambert S. B. Rotavirus vaccines: opportunities and challenges. Hum Vaccin. 2009; 5: pp. 57-69. [PubMed]

Linhares A. C., Velazquez F. R., Perez-Schael I., Saez-Llorens X., Abate H., Espinoza F., et al. Efficacy and safety of an oral live attenuated human rotavirus vaccine against rotavirus gastroenteritis during the first 2 years of life in Latin American infants: a randomised, double-blind, placebocontrolled phase III study. Lancet. 2008; 371: pp. 1181-9.

Lopez P., Linhares A., Perez-Schael I., Ruiz-Palacios G., Costa Clemens S., Sanchez N., et al. Early protection against severe rotavirus gastroenteritis-RIX4414 experience in Latin America. In: 24th Annual Meeting of the European Society of Infectious Diseases; 2006 May 3-5. Basel, Switzerland: 2006.

Ministry of Health of Ukraine, the Order No. 595. "Regime of preventive vaccinations in Ukraine and quality control and treatment of immunological preparations"

http: //www . muoz . cv . ua/2011/11/01/nakaz-moz-ukrayini-vd-16092011595-pro-poryadok-provedennya-proflaktichnih-scheplen-v-ukrayinta-kontrol-yakost-y-obgu-medichnih-munobologchnih-preparatv.html

Ogilvie I., Khoury H., El. Khoury A. C., Goetghebeur M. M. Burden of rotavirus gastroenteritis in the pediatric population in Central and Eastern Europe: serotype distribution and burden of illness. Hum. Vaccin. 2011 May; 7(5): pp. 523-33. Epub 2011 May 1.

Parashar U.D., Gibson C. J., Bresse J. S., Glass R. I. Rotavirus and severe childhood diarrhea// Emerg. Infect. Dis. - 2006. - \#12. - P. 304-306.

Parashar U. D., Burton A., Lanata C., Boschi-Pinto C., Shibuya K., Steele D., et al. Global mortality associated with rotavirus disease among children in 2004. J Infect Dis. 2009; 200: pp. 9-15.

Parashar U. D., Hummelman E. G., Bresee J. S., Miller M. A., Glass R. I. Global illness and deaths caused by rotavirus disease in children. Emerg Infect Dis. 2003; 9: pp. 565-572.

PubMed. http://Www.ncbi.nlm.nih.gov/pubmed/

Rose J., Hawthorn R. L., Watts B., Singer M. E. Public health impact and cost effectiveness of mass vaccination with live attenuated human rotavirus vaccine (RIX4414) in India: model based analysis. BMJ. 2009 Sep 25; 339:b3653.

Rose J., Singer M. E. Projecting vaccine efficacy: accounting for geographic strain variations. Pharmacoeconomics. 2008; 26(3): pp. 185-9.

Ruiz-Palacios G. M., Perez-Schael I., Velazquez F. R., et al. Safety and efficacy of an attenuated vaccine against severe rotavirus gastroenteritis. N. Engl. J. Med. 2006 Jan 5; 354 (1): pp. 11-22

Ruuska T., Vesikari T. Rotavirus disease in Finnish children: use of numerical scores forclinical severity ofdiarrhoeal episodes. Scand. J. Infect. Dis. 1990; 22: pp. 259-67.

Salinas B., Perez Schael I., Linhares A. C., et al. Evaluation of safety, immunogenicity and efficacy of an attenuated rotavirus vaccine, RIX4414: a randomized, placebo-controlled trial in Latin American infants. Pediatr. Infect. Dis. J. 2005 Sep; 24 (9): pp. 807-16

Solovyov S., Trokhimenko O., Dzyublyk I. Molecular typing of rotaviruses, isolated on the territory of Ukraine // Clinical microbiology and infection. Special Issue: Abstracts of the 21 st. ECCMID/27th ICC, Milan, Italy, 7-10 May 2011, Volume 17, Issue Supplements 4, S735.

Sonnenberg F. A., Beck J. R. Markov models in medical decision making: A practical guide. Med Decis Making 13: pp. 322-338, 1993.

Soriano-Gabarro M., Mrukowicz J., Vesikari T., Verstraeten T. Burden of rotavirus disease in European Union countries. Pediatr Infect Dis J. 2006; 25: pp. 7-11. 
Soriano-Gabarro M., Mrukowicz J., Vesikari T., Verstraeten T. Burden of rotavirus disease in European Union countries. Pediatr. Infect. Dis. J. 2006; 25: pp. 7-11.

Velazquez F. R., Matson D. O., Calva J. J., Guerrero L., Morrow A. L., Carter-Campbell S., et al. Rotavirus infections in infants as protection against subsequent infections. N. Engl. J. Med. 1996; 335: pp. 1022-8.

Vesikari T., Karvonen A., Puustinen L., et al. Efficacy of RIX4414 live attenuated human rotavirus vaccine in Finnish infants. Pediatr. Infect. Dis. J. 2004 Oct. 23 (10): pp. 937-43

World Health Organization. Immunization profile - Ukraine. Geneva, WHO, 2008. http://apps.who.int/immunization_monitoring/en/globalsummary/tim eseries/tscoveragebycountry. cfm? C=UKR

World Health Organization. World Health Statistics 2011. Geneva, WHO, 2011. http://wWw. who. int/whosis/whostat/2011/en/

World Health Organization. External review of burden of disease attributable to rotavirus, 2005. [2 Nov. 2009]. http://www.who.int/immunization_monitoring/burden/Rota_virus_Q5_ mortality_estimates_external_review_report_2006_may.pdf

Крамарев С. О. Гострі кишкові інфекції у дітей: навч.-метод. посіб. для лікарів-інтернів / за ред. проф. С. О. Крамарева. - К.: Червона Рута-Турс, 2007. - 132 с.

Недашківська Н.І. Оцінювання реверсу рангів в методі аналізу ієрархій // Системні дослідження та інформаційні технології. - 2005. - № 4. - С. 120-130.

Подколзин A. T. Адаптированная к практическому применению методика [P]G генотипирования ротавирусов группы А / А. Т. Подколзин, Е. Б. Фенске, Н. Ю. Абрамычева и др. // Молекулярная диагностика. - 2007: сб. тр. 6-ой Всерос. науч.-практ. конф. с международным участием. - М. 2007. - Т. 3. - С. 284-286.

Шунько Є. $С$. Ротавіруси групи А та аденовіруси у новонароджених 3 перинатальною патологією: клініко-вірусологічне спостереження / С. С. Шунько, І. В. Дзюблик, Л. В. Омельченко, С. О. Соловьев // Соврем. педиатрия. - 2011. - № 2. - С. 89-95. 